Мазур А. П., д-р мед. наук, завідувач відділу анестезіології та інтенсивної терапії

Гурін П. В., лікар-анестезіолог відділення загальної та трансплантаційної анестезіології

Бабіч М. М., лікар-анестезіолог відділення загальної та трансплантаційної анестезіології

Борисенко А. О., лікар-анестезіолог відділення загальної та трансплантаційної анестезіології

ДУ «Національний інститут хірургії та трансплантології імені О. О. Шалімова НАМН України», м. Київ, Україна

\title{
Алгоритм прийняття рішень під час коронарного шунтування на працюючому серці
}

\begin{abstract}
Резюме. Вивчені зміни гемодинаміки, які виникають на етапах коронарного шунтування (КШ) на працюючому серці. На основі змін серцевого індексу (CI), тиску в легеневій артерії, артеріального тиску (АТ) та сатурації змішаної венозної крові, що виникали під час операції, розроблено алгоритм прийняття рішень, який дозволив оптимізувати анестезіологічне забезпечення у цієї категорії пацієнтів.

У дослідження включено 75 пацієнтів, оперованих у НІХТ імені О. О. Шалімова з приводу ішемічної хвороби серця (IXC), яким було виконано КШ на працюючому серці. У групу дослідження увійшло 40 пацієнтів, у яких в інтраопераційному періоді застосовували оптимізований алгоритм прийняття рішень на основі комплексного аналізу факторів, що призводили до порушень гемодинаміки на етапах КШ. Групу порівняння становили 35 пацієнтів, у яких корекцію гемодинаміки проводили, переважно орієнтуючись на показники АТ. Отримані результати продемонстрували, що при застосуванні оптимізованого алгоритму прийняття рішень у разі гемодинамічних порушень зменшується потреба в симпатоміметичній та полемічній підтримці, скорочується час перебування у відділенні інтенсивної терапії та стаціонарі.
\end{abstract}

Ключові слова: коронарне шунтування, серцевий індекс, порушення гемодинаміки.

Протягом останніх років як в Україні, так і в світі відбувається значне збільшення кількості операцій коронарного шунтування (КШ) без використання штучного кровообігу [1]. На відміну від коронарного шунтування із застосуванням штучного кровообігу, оперативні втручання, виконані за методикою «працюючого серця», мають такі переваги: не відбувається активації протеолітичних ферментів та системної запальної відповіді, відсутній негативний вплив штучного кровообігу на імунну систему, не виникає споживання факторів згортання та тромбоцитів [2, 3, 4].

Повна експозиція коронарних артерій при багатосудинних ураженнях можлива лише при дислокації серця із фізіологічного положення в разі застосування систем стабілізації (вакуумних чи компресійних). 3 іншого боку, стабілізаційні системи знижують регіонарну скоротливість міокарда, а в поєднанні з періодами оклюзії коронарної артерії (коли не використовується інтракоронарний шунт) призводять до теплової ішемії $[5,6]$. Тому зміни гемодинаміки $є$ найчастішими проявами під час КШ на працюючому серці, які найбільше виражені при шунтуванні огинаючої гілки (ОГ) лівої коронарної артерії (ЛКА) та дистальних гілок правої коронарної артерії (ПКА). Це проявляється у зниженні серцевого індексу (СI), артеріального тиску (АТ), зміні показників тиску в легеневій артерії (ТЛА), центрального венозного тиску (ЦВТ) та сатурації змішаної венозної крові $\left(\mathrm{SvO}_{2}\right)$ [7]. Тому вибір оптимального рішення під час реваскуляризації міокарда на працюючому серці (зміна режиму інфузійної терапії, використання симпатоміметичних чи вазоконстрикторних препаратів та їх комбінація тощо) при виникненні системної гіпотензії залишається до кінця не вирішеною проблемою.

Мета дослідження. Розробити алгоритм прийняття рішень для корекції гемодинамічних порушень на етапах коронарного шунтування на працюючому серці.

Матеріали та методи дослідження. В основу дослідження покладено проспективний аналіз проведених оперативних втручань пацієнтів, яким із січня 2015 по березень 2017 року було виконано ізольоване КШ на працюючому серці. Після розробки оптимізованого алгоритму прийняття рішень під час КШ на працюючому серці з метою підтвердження його ефективності, проведено порівняльний аналіз з групою пацієнтів, яким КШ на працюючому серці було виконано без застосування цього алгоритму. Пацієнтів розподілили на дві групи: у 1-у групу (групу дослідження, 40 осіб) увійшли пацієнти, в яких в інтраопераційному періоді застосовували оптимізований алгоритм прийняття 
рішень на основі комплексного аналізу факторів, що призводили до порушення гемодинаміки на етапах КШ; у 2-у (групу порівняння, 35 осіб) - пацієнти, яким корекцію гемодинаміки проводили, переважно орієнтуючись на показники артеріального тиску (АТ).

Характеристика пацієнтів. Статистичної різниці між групами пацієнтів виявлено не було ( $p>0,05)$. Середній вік пацієнтів становив 59,9 \pm 8,8 та 61,4 \pm 8,1 року. Середня фракція викиду (ФВ) лівого шлуночка $-57,9 \pm 5,9 \%$ та $61,2 \pm 6,8 \%$. Середня кількість дистальних анастомозів - 3,2 $\pm 0,8$ та $3,1 \pm 0,6$. За шкалою EUROSCORE 2 середнє значення періопераційного ризику досягало $1,8 \pm 0,33$ та $1,76 \pm 0,35$. Критеріями виключення пацієнтів із дослідження були: ФВ лівого шлуночка менша за $50 \%$, передопераційний рівень креатиніну плазми крові $>140$ мкмоль/л, передопераційний рівень гемоглобіну < 120 г/л, кількість тромбоцитів $<180 \times 10^{9} /$ л, доопераційна коагулопатія, печінкова дисфункція (аланінамінотрансфераза (АЛТ) > 40 ОД/л, аспартатамінотрансфераза $(\mathrm{ACT})>40$ ОД/л), повторна операція КШ, ургентне оперативне втручання. Усім пацієнтам антитромбоцитарні препарати відмінили більше ніж за 5 днів до оперативного втручання.

Анестезія та моніторинг. Усім пацієнтам операційні втручання були виконані в умовах тотальної інгаляційної анестезії севофлураном з керованим диханням. Концентрація севофлурану на видиху підтримувалася в межах 0,6-0,8 МАК. Потік свіжого газу становив 1 л/хв (кисень + повітря) з концентрацією кисню 50$100 \%$ залежно від етапу операції та клінічної ситуації. Штучну вентиляцію легень (ШВЛ) здійснювали в режимі нормовентиляції під контролем $\mathrm{PCO}_{2}$ на видиху.

Інтраопераційно до початку оперативного втручання пацієнтам обох груп був налагоджений ЕКГмоніторинг у стандартних і грудних відведеннях з аналізом сегмента ST, проводили пульсоксиметрію, встановлювали периферичний венозний катетер і катетер у променеву артерію для реєстрації АТ інвазивним методом. Після індукції в анестезію та інтубації трахеї встановлювали центральний венозний катетер для проведення інфузії рідини, реєстрації ЦВТ та моніторингу сатурації венозної крові $\left(\mathrm{SvO}_{2}\right)$. У пацієнтів 1-ї групи після стернотомії виконували катетеризацію легеневої артерії (ЛА) внутрішньовенною канюлею 20 g. Це дозволяло вимірювати тиск у ЛА (ТЛА), контролювати волемію, а також брати проби крові для визначення кислотно-основного стану (КОС), лактату та розрахунку артеріо-венозної різниці за киснем.

Пацієнтам 1-ї групи проводили вімірювання CI, загального периферичного судинного опору (ЗПСО).

CI розраховували за формулою:

$\mathrm{CI}=\left(\mathrm{VO}_{2} /\left(1,34 \times \mathrm{Hb} \times\left(\mathrm{SaO}_{2}-\mathrm{SvO}_{2}\right)+\right.\right.$

$\left.+\left(0,003 \times \mathrm{PaO}_{2}\right)\right) /$ ППТ, де $\mathrm{VO}_{2}$ - споживання кисню, мл/хв;

1,34 - константа Гюфнера (відображає здатність гемоглобіну зв'язувати кисень);

$\mathrm{Hb}$ - концентрація гемоглобіну в крові, г/л;

$\mathrm{SaO}_{2}$ - сатурація гемоглобіну артеріальної крові, \%;

$\mathrm{SvO}_{2}$ - сатурація гемоглобіну венозної крові, \%;

$\mathrm{PaO}_{2}$ - парціальний тиск кисню в артеріальній кро-

ві, мм рт. ст.;

ППТ - площа поверхні тіла.

Показник $\mathrm{VO}_{2}$ обчислювали за різницею вмісту кисню в контурі газоаналізатора апарата ШВЛ. Отриманий результат множили на величину хвилинного об’єму дихання.

Загальний периферичний судинний опір розраховували за формулою:

ЗПСО $=80$ (АТcep. - ЦВТ) $/($ СВ/ППТ $)$,

де АТсер. - середній АТ;

СВ - серцевий викид;

ППТ - площа поверхні тіла.

Статистична обробка даних. Статистичний аналіз матеріалу проводили за допомогою стандартних методів із застосуванням пакету прикладних програм «MSExcel» та «StatPlus 2007 Professional». Оцінювали середнє значення, стандартні помилки, достовірність відмінностей. Для оцінювання міжгрупової різниці застосовували параметричний t-критерій Стьюдента, при визначені зв'язків між показниками - кореляційний аналіз за Пірсоном.

Результати та обговорення. У дослідженні оцінювали такі параметри гемодинаміки: у пацієнтів 1-ї групи ЧСС, АТcep., СІ, ТЛА. У пацієнтів 2-ї групи - ЧСС, ATcep. Етапи інтраопераційного періоду:

1. Початок операції.

2. Формування дистального анастомозу між лівою внутрішньою грудною артерією (ЛВГА) та передньою міжшлуночковою гілкою лівої коронарної артерії (ПМШГ ЛКА).

3. Формування дистального анастомозу аутовеною між аортою та ПКА.

4. Формування дистального анастомозу аутовеною між аортою та огинаючою гілкою лівої коронарної артерії (ОГ ЛКА).

5. Завершення операції.

У пацієнтів групи дослідження всі вищеперераховані параметри досліджувались на всіх етапах операції (ТЛА починали досліджувати після стернотомії, оскільки тільки після цієї маніпуляції можливе проведення катетеризації ЛА). У пацієнтів групи порівняння на цих етапах операції досліджували АТсер. та частоту серцевих скорочень (ЧСС).

\section{Eman 1. Початок операції}

На початку оперативного втручання показники CI, ЧСС та АТсер. мали тенденцію до збільшення. Це було пов’язано з активацією симпато-адреналової системи 
на хірургічну активність. У разі підвищення ЧСС > 90/ хв. та АТсер. $>90$ мм рт. ст. збільшували глибину анестезії до 1 МАК, підвищували дозу фентанілу до 5 мкг/кг/год, використовували метопролол внутрішньовенно. При порівнянні показників ЧСС у пацієнтів 1-ї та 2-ї груп статистичної різниці не спостерігалося $(65,6 \pm 7,7$ та $68,3 \pm 6,1, p=0,04)$. Показники АТсер. в групі порівняння дещо перевищували показники в пацієнтів 1-ї групи $(92,2 \pm 10,6$ та 94,7 $\pm 12,3, \mathrm{p}=0,34)$. Після катетеризації ЛА в пацієнтів 1-ї групи реєстрували ТЛА. При зниженні ТЛА сер. < 20 мм рт. ст. використовували болюс рідини 5 мл/кг (рисунок 1). Тиск ЛА вище 40 мм рт. ст. зареєстровано не було.

Eman 2. Формування дистального анастомозу між ЛВГА та ПМШГ ЛКА

Анастомоз між ЛВГА та ПМШГ ЛКА було виконано в усіх пацієнтів обох груп. При встановленні епікардіального стабілізатора не спостерігалося значних змін гемодинаміки. АТсер. становив 86,6 \pm 7,9 мм рт. ст. у пацієнтів 1-ї групи та $84,5 \pm$ 7,7 у пацієнтів 2-ї групи $(\mathrm{p}=0,25)$. Частота серцевих скорочень також не відрізнялась між групами пацієнтів і сягала $74,5 \pm 6,8$ за 1 хв та $72,3 \pm 7,3$ за 1 хв $(\mathrm{p}=0,18)$. Серцевий індекс на етапі формування дистального анастомозу досягав $2,62 \pm 0,35$ л $/$ хв $/ \mathrm{M}^{2}$, а величина його зниження після накладання дистального анастомозу - $5 \%$. ТЛА та ЦВТ підвищувалися незначно і становили $21,2 \pm$ 2,2 мм рт. ст. та 45,6 $\pm 13,1$ мм вод. ст. Симпатоміметичні та вазопресорні препарати на цьому етапі не застосовувалися в пацієнтів обох груп.

Eтап 3. Формування дистального анастомозу між аортою та ПКА

Шунтування ПКА проводили у 31 пацієнта (77,5\%) 1-ї групи та у 28 пацієнтів (80 \%) 2-ї групи. На цьому етапі операційний стіл переводили в положення Тренделєнбурга та змішували ліворуч. Накладання стабілізатора зумовлювало компресію правого шлуночка.

У пацієнтів 1-ї групи спостерігалося зниження АТсер. на $14,8 \%$ ( з 85,3 \pm 7,8 до 72,7 $\pm 6,2$ мм рт. ст.), підвищення ЦВТ на $66 \%$, ТЛА на $53 \%$, ЧСС на $30 \%$. Серцевий індекс знижувався на $16 \%$ (з 2,6 \pm 0,27 до 2,2 \pm 0,28 л/хв $\left./ \mathrm{M}^{2}\right)$. У разі зниження ЧСС ми використовували зовнішню передсердну електрокардіостимуляцію (ЕKC), задаючи ЧСС в межах 80-90/хв. Аналіз показника $\mathrm{SvO}_{2}$ виявив незначне його зниження (з 73,8 $\pm 3,8$ до $71,6 \pm 3,3 \%)$, а визначивши ЗПСО - отримали його значення в межах $680 \pm 123$ дин ${ }^{*} \mathrm{~cm}^{-5}$. Тому при зниженні АТсер. нижче 70 мм рт. ст. ми використовували інфузію норадреналіну в дозі 50-150 нг/кг/хв до досягнення АТсер. 70 мм рт. ст. і вище (див. рисунок 1). Рівень лактату крові після закінчення шунтування коронарної артерії становив 1,2 $\pm 0,22$ ммоль/л.

У пацієнтів 2-ї групи зниження АТсер. становило $12,8 \%$ (з 81,4 $\pm 8,6$ до 71,0 \pm 5,9 мм рт. ст.), а для корекції ЧСС використовували розчин атропіну
(0,5-1 мг внутрішньовенно). У разі зниження АТсер. застосовували інфузію допаміну (6-9 мкг/кг/хв), але у 8 пацієнтів (29\%) були зареєстровані випадки тахікардії > 100/хв, що було небажаним при накладанні анастомозу.

Етап 4. Формування дистального анастомозу між аортою та ОГ ЛКА

Шунтування ОГ ЛКА виконували 30 (75 \%) пацієнтам 1-ї групи та 28 (75\%) пацієнтам 2-ї групи.

Для зручності експозиції бокової поверхні, серце зміщували праворуч і догори, використовували положення Тренделєнбурга і ротацію операційного стола праворуч. Такі маніпуляції призводили до погіршення наповнення шлуночків, недостатності атріовентрикулярних клапанів, а при огляді гілок огинаючої артерії хірург тимчасово створював компресію на лівий шлуночок, що посилювало гемодинамічні порушення.

У пацієнтів 1-ї групи зниження АТсер. досягало $20 \%$ (з 78,3 \pm 3 до 65,3 \pm 6 мм рт. ст.), порушень 3 боку ЧСС не спостерігалося (80,5 $\pm 6,6$ за 1 хв), ТЛА дорівнював $27,4 \pm 2,2$ мм рт. ст. Серцевий індекс знижувався на 26,7 \% (з 2,51 \pm 0,26 до 1,84 $\pm 0,14$ л/хв/ $/ \mathrm{M}^{2}$ ). При виборі вазоактивного препарату ми застосовували диференційований підхід (див. рисунок 1). У пацієнтів 1-ї групи лише в 1 особи при зниженні АТсер. нижче 70 мм рт. ст. $\mathrm{SvO}_{2}$ був нижчим за $65 \%$. У цьому випадку ми застосували інфузію допаміну в дозі 6 мкг/кг/хв до досягення АТсер. вище 70 мм рт. ст. В усіх інших випадках цей показник був вищим за $65 \%$ і становив у середньому 74,2 $\pm 2,8 \%$. Загальний периферичний судинний опір досягав $732 \pm 167$ дин ${ }^{*} \mathrm{c}^{*} \mathrm{~cm}^{-5}$, що дозволяло нам при зниженні АТсер. застосовувати інфузію норадреналіну в таких самих дозах, як і на етапі шунтування ПКА.

У пацієнтів 2-ї групи зниження АТсер. становило $22 \%$ (з 81,2 \pm 5,1 до 63,3 \pm 7,4 мм рт. ст.). Для корекції артеріальної гіпотензії використовували інфузію допаміну (8-10 мкг/кг/хв), а в 3 випадках переходили на інфузію адреналіну в дозі 100-300 нг/кг/хв. В 1 випадку відбувся перехід до штучного кровообігу.

\section{Eman 5. Завершення операціï}

Цей етап характеризувався нормалізацією показників АТсер., ЧСС у пацієнтів обох груп, а також СІ у пацієнтів 1-ї групи $\left(2,99 \pm 0,53\right.$ л/хв/ $\left.\mathbf{M}^{2}\right)$. Потреба в інфузії норадреналіну залишалась у 2 (5\%) пацієнтів 1-ї групи, а 6 (17 \%) пацієнтів 2-ї групи потребували подальшої інфузії допаміну.

Порівняльна характеристика післяопераційного періоду в пацієнтів досліджуваних груп

Порівняльний аналіз післяопераційного періоду між групами пацієнтів проводили за такими критеріями: час перебування на ШВЛ, у відділенні інтенсивної терапії (BIT), у стаціонарі, потреба в симпатоміметичній підтримці, інтраопераційний баланс інфузії та кількість уведеної рідини (таблиця 1). 
Мазур А. П. / Алгоритм прийняття рішень під час коронарного шунтування на працюючому серці
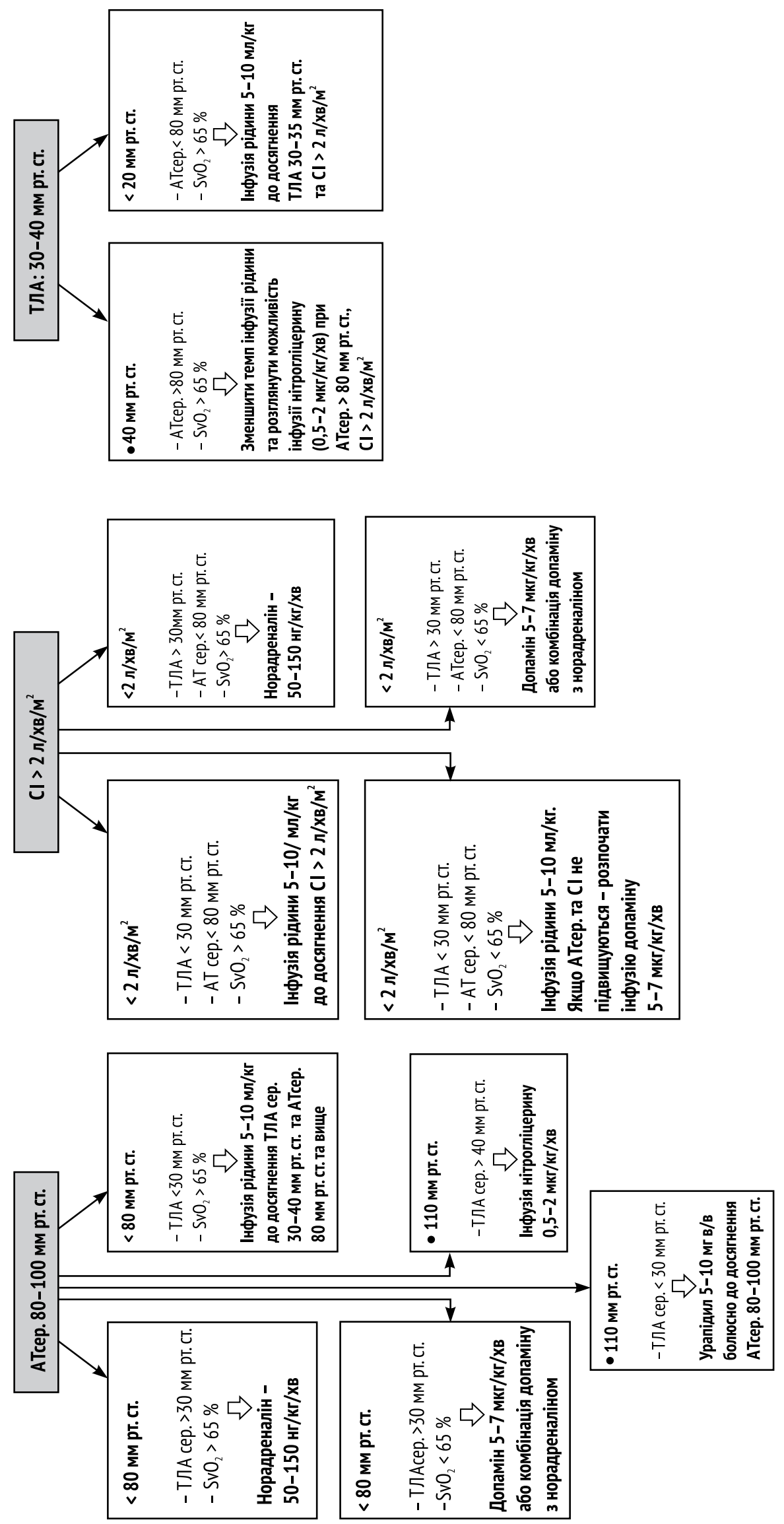


\section{Таблиця 1}

Порівняльна характеристика післяопераційного періоду

\begin{tabular}{lccc} 
& $\begin{array}{c}\text { Группа 1, } \\
\mathbf{n = 4 0 ,} \\
\mathbf{M} \pm \mathbf{S D}\end{array}$ & $\begin{array}{c}\text { Група 2, } \\
\mathbf{n = 3 5 ,} \\
\mathbf{M} \pm \mathbf{S D}\end{array}$ & $\mathbf{p}$ \\
\hline Показник & $3,34 \pm 1,5$ & $3,5 \pm 1,62$ & 0,32 \\
\hline Час ШВЛ, години & $47,3 \pm 3,8$ & $54,9 \pm 3,7$ & 0,0003 \\
\hline Перебування у ВІТ, години & $6,9 \pm 0,8$ & $8,1 \pm 1,2$ & 0,0001 \\
\hline $\begin{array}{l}\text { Час перебування у } \\
\text { стаціонарі п/о, доби }\end{array}$ & 0 & $6(17 \%)$ & 0 \\
\hline $\begin{array}{l}\text { Потреба в інфузії } \\
\text { симпатоміметиків }\end{array}$ & $2402 \pm 578$ & $2897 \pm 635$ & 0,0007 \\
\hline $\begin{array}{l}\text { Кількість уведеної рідини } \\
\text { інтраопераційно, мл }\end{array}$ & $1235 \pm 352$ & $1641 \pm 419$ & 0,0002 \\
\hline $\begin{array}{l}\text { Інтраопераційний баланс } \\
\text { рідини, мл }\end{array}$ & & &
\end{tabular}

Як можна побачити із таблиці 1, пацієнти 1-ї групи мали менший час перебування у BIT та стаціонарі після проведеного оперативного втручання. Також жоден пацієнт 1-ї групи не потребував інфузії симпатоміметичних препаратів, на відміну від пацієнтів 2-ї групи, де інфузія допаміну продовжувалась у 6 пацієнтів. Інтраопераційна волемія та баланс рідини були достовірно нижчими в пацієнтів групи дослідження.

Проведений аналіз періопераційного періоду дав змогу розробити оптимізований алгоритм прийняття рішень щодо ситуацій, які можуть виникати в інтраопераційному періоді операцій КШ на працюючому серці. Ці рекомендації стосуються СІ, ТЛА та АТсер.

\section{Висновки}

1. Вибір вазоактивного препарату при зниженні ATcep. та СІ під час шунтування гілок ПКА та ОГ ЛКА потребує диференційованого підходу й залежить від рівня волемії та величини ЗПСО.

2. Катетеризація ЛА дозволяє контролювати рівень волемії та зменшити інтраопераційну інфузію рідини.

3. Оптимізований алгоритм прийняття рішень під час планових операцій КШ на працюючому серці дав змогу зменшити час перебування пацієнтів у ВIT та стаціонарі.

\section{Список використаних джерел References}

1. Лазоришинець ВВ. НІССХ імені М. М. Амосова: можливості сучасної серцево-судинної хірургії повинні бути доступні для всіх категорій населення незалежно від місця проживання. Вісник серцево-судинної хірургії. 2017;2(вип. 28):8-17.

Lazoryshynets VV. [National Amosov Institute: possibilities of modern cardiovascular surgery should be accessible to all population categories of the regardless of residence place. Cardio-vascular surgery herald. 2017;2(issue 28):8-17. Ukrainian.

2. Bierbach B, Bomberg H, Pritzer H, Prabhu S, Petzina $\mathrm{R}$, Kempski $\mathrm{O}$, et al. Off-pump coronary artery bypass prevents visceral organ damage. Interact Cardiovasc Thorac Surg. 2014 Jun;18(6):717-26. https://doi.org/10.1093/ icvts/ivu063

3. Athanasopoulos LV, Athanasiou T. Off-pump coronary artery bypass grafting in left main stem stenosis: outcomes, concerns and controversies. J Thorac Dis. 2016 Nov; 8(Suppl 10): S787-S794. https://doi.org/10.21037/jtd.2016.09.72

4. Wang J, Zheng H, Chen CL, Lu W, Zhang YQ. Sevoflurane at 1 MAC provides optimal myocardial protection during offpump CABG. Scand Cardiovasc J. 2013 Jun;47(3):175-84. https://doi.org/10.3109/14017431.2012.760749

5. Chang WI, Kim KB, Kim JH, Ham BM, Kim YL. Hemodynamic changes during posterior vessel offpump coronary artery bypass: comparison between deep pericardial sutures and vacuum-assisted apical suction device. Ann Thorac Surg. 2004 Dec;78(6):2057-62. https:// doi.org/10.1016/j.athoracsur.2004.05.059

6. Louagie Y, Jamart J, Broka S, Collard E, Scavée V, Gonzalez M. Off-pump coronary artery bypass grafting: a casematched comparison of hemodynamic outcome. Eur $\mathrm{J}$ Cardiothorac Surg. 2002 Oct;22(4):552-8. https://doi. org/10.1016/s1010-7940(02)00400-1

7. Yoon SS, Bang JH, Jeong SS, Jeong JH, Woo JS. Risk Factors of On-Pump Conversion during Off-Pump Coronary Artery Bypass Graft. Korean J Thorac Cardiovasc Surg. 2017 Oct;50(5):355-62. https://doi.org/10.5090/ kjtcs.2017.50.5.355

\title{
The Algorithm of Decision Making During Off-Pump Coronary Artery Bypass Grafting
}

\author{
Mazur A., Gurin P., Babich M., Borisenko A.
}

Shalimov National Institute of Surgery and Transplantology of National Academy of Medical Science of Ukraine, Kyiv, Ukraine

\section{Abstract}

Introduction. Over the past 20 years, both in Ukraine and in the world, the number of coronary artery bypass grafting $(\mathrm{CABG})$ surgical procedures has shown significant increase. Complete exposition of coronary arteries in multivariate damage is possible only with the dislocation of the heart from physiological position in case of the use of stabilization systems (vacuum or compression). Therefore, hemodynamic disorders are the most common manifestations during offpump CABG and are most pronounced when the circumflex branch of left coronary artery (LCA) and the distal branches of the right coronary artery (RCA) are shunted. This is manifested in lowering the cardiac index (CI), blood pressure (BP), changes in pulmonary artery pressure (PAP), central venous pressure (CVP) and saturation of mixed venous blood $\left(\mathrm{SvO}_{2}\right)$. 
Therefore, the choice of the optimal solution during off-pump CABG (changing the mode of infusion therapy, the use of sympathomimetics or vasoconstrictors and their combination, etc.) in case of systemic hypotension remains an unresolved problem.

Materials and methods. The study was based on a prospective analysis of surgical interventions (off-pump CABG) performed in patients from January 2015 through March 2017. Following the development of an optimized decision-making algorithm during off-pump CABG in order to confirm its effectiveness, a comparative analysis was performed with a group of patients who had performed an off-pump CABG without using this algorithm. Patients were divided into two groups: group 1 (study group, 40 patients) included patients who had optimized decision-making algorithm in the intraoperative period on the basis of a complex analysis of the factors leading to hemodynamic disorders during off-pump CABG: CI, PAP, $\mathrm{BP}, \mathrm{SvO}_{2}$; group 2 (comparison group, 35 patients) included patients who underwent hemodynamic repair, focusing mainly on BP values.

Results and discussion. The most marked violations of hemodynamics were observed in the formation of distal anastomoses between the aorta and the RCA and circumflex branch of the LCA. This was manifested in the decrease in CI and $\mathrm{BP}$, and, in some cases, $\mathrm{SvO}_{2}$. The value of systemic vascular resistance (SVR) at the stages of the formation of distal anastomoses was below $800 \mathrm{dyn} * \mathrm{sec}^{*} \mathrm{~cm}^{-5}$. Therefore, with the decrease in CI and BP in patients of group 1, norepinephrine was used at the dose of $50-150 \mathrm{ng} / \mathrm{kg} / \mathrm{min}$. This allowed to increase the mean BP above $80 \mathrm{mmHg}$ and CI above $21 / \mathrm{min} / \mathrm{m}^{2}$. In patients of group 2 with decreased BP, dopamine infusion was used at a dose of $6-9 \mu \mathrm{g} / \mathrm{kg} / \mathrm{min}$, which in $29 \%$ of cases caused tachycardia ( $>100 \mathrm{bpm})$, which was not desirable during the distal anastomosis overlaying stages. Control of infusion with PAP allowed to reduce the total volume of intraoperative infusion $(2402 \pm 578 \mathrm{ml}$ vs $2897 \pm 635 \mathrm{ml}, \mathrm{p}=0.0007)$ and reach intraoperative fluid balance $(1235 \pm 352 \mathrm{ml}$ vs $1641 \pm 419 \mathrm{ml}, \mathrm{p}=0.0002)$. Patients in group 1 showed significantly shorter length of stay at the intensive care unit (ICU) and in hospital after the surgical intervention.

Conclusions. The optimized decision-making algorithm during off-pump CABG has allowed to reduce intraoperative infusion therapy, as well as shorten the length of stay at ICU and duration of hospitalization.

Keywords: coronary artery bypass grafting, cardiac index, hemodynamic disorders.

Стаття надійшла в редакцію 24.07.2019 р. 